\title{
Medikal/Estetik Televizyon Programlarının Muhafazakâr Kadın İzleyici Alımlamasına Yönelik Bir Etnografik Çalışma
}

\section{An Ethnographic Research About The Conservative Female Audience's Perception Of Medical/Aesthetic Television Programs}

\author{
Gülhan Gündoğdu ${ }^{1}$ \\ Doktora Öğrencisi \\ İstanbul Ticaret Üniversitesi \\ Medya ve İletişim Çalışmaları Doktora Programı, İstanbul
}

Özet: Bu çalışma, muhafazakâr kimlik bağlamında kendini konumlandıran kadın izler kitlenin, medikal/sağlık programlarının alımlamasına yönelik bir etnografik çalışmadır. Kendini muhafazakâr kimlikle konumlandıran 7 kadın izleyici ile gerçekleştirilen fokus grup çalışmasında, sağlık programlarına yönelik kadın izleyici yaklaşımları gözlemlenmiştir. Çalışma, televizyon kanallarında yayınlanan medikal/estetik konulu sağlık program içeriklerinin, kendini muhafazakâr kimlik altında konumlandıran kadın izleyiciler tarafından nasıl alımlandığı ve bu yöndeki tüketim davranışlarının nasıl değiştiğini, anlamak amacıyla yapılmıştır. Çalışmada; katılımcılar her ne kadar eğitimli ve medyanın bu alandaki etkisinin farkında olan, yüksek bilince sahip bir grup olsa da sağlık söz konusu olduğunda, estetik operasyonun tercihi, muhafazakâr kimliğin veya dini referansların önüne geçtiği gözlemlenmiştir. Çalışma grubu, sağlık gibi gerekçelerle tüketim toplumuyla, daha çok bir meta dönüşen sağlığın bu tarafını rasyonelleştirmiştir. Kamusal alanda kimliğiyle var olma mücadelesi veren muhafazakâr kadın, medya aracılığıyla, yoğun bir şekilde sunulan medikal/estetik sağlık programlarının tüketimi karşısında, her ne kadar etkin olarak kendini görse de kaçınılmaz bir şekilde edilgen bir özne olarak konumlanabileceği bulguları tespit edilmiştir. araştırmaları.

Anahtar Kelimeler: Muhafazakâr kadın kimliği, Medikal/estetik sağlık programları, Fokus grup, İleyici

Extended abstract:Although the history of communication tools is very old, the researches for the effects of these tools on the audience has become a focus of interest in the early 20th century. One of the most important reasons for this interest is the growing concern about the delivery of manufactured goods to mass buyers in an increasing understanding of capitalist production.

At the beginning, tThe mass communication was originally thought to be the process of transmitting the public message to the sender. In this sense, the first time mass media theory explores "what the media does to people", the audience's use of media and the interpretation of messages are neglected.

In time, the message given by the mass media communication tools has a very different effect on the audience creating the changing structure of mass communication models; cultural, interpreting, and critical approach models have been developed. In this way, they created "active/passive audience" debates which are fundamental problems in mass communication researches. Taking into account the effects of mass media, Denis McQuail has applied a triple classification to the researches done in this field (Tokgöz, 2015, s. 26): The

${ }^{1}$ gundogdugulhan@gmail.com, gulhan.gundogdu@istanbulticaret.edu.tr 
Period of Strong Impact (1920-1940), The Period of Limited Impact (1940-1960, and Strong Impact Period again (1960 and after)

It is accepted that the influences of mass media (newspapers, radio) in the 1920-1940 is called the period of strong influence. The general approach in this period is that the message sent on the mass media finds individuals and leaves a great influence on the individuals.

The period of the limited influence that the messages given by mass media are considered to have not so great effect on the viewer / listener / reader. The Limited Impact Model supported more of the communications industry and communications producers.

After 1960, the powerful effects of mass media began to be mentioned again. David Morley interprets this as "... from" effects "to" functions "... and back again" (Morley, 1992, s. 44). In this period, television is now more active on the audience.

Stuart Hall's, "Coding-encoding" pioneering work, has given a new perspective to audience researches. As long as the messages contain more than one meaning, Hall indicates in the "Coding-encoding" that the media messages are read by the audience as negotiators. Hall emphasizes that the ideological field was established through television but was threatened by multiple readings or critical interpretations of this field, emphasizes that the viewer passes from the passive subject to the active.

The word "conservatism" is derived from the Latin word "Conservation" and spread to the world from the Frenchword "Conservateur". The concept of "conservative" on the daily basis has different meanings. This concept may have the meanings specified by the act of modest or cautious behavior, a traditionally harmonious way of life, fear of change or rejection of change. Culture in terms of conservatism it symbolizes the past not the future.

The emergence of conservatism concerns the emergence of modernitarian and modernization processes. An ideology and doctrine shaped in the context of the opposition to modernization. For this reason, conservatism is perceived as anti-modern (Yücebaş, 2013, s. 8,18). After 1980, conservatism reached a level close to today's liberalism.

In Turkey, conservatism emerged with the Republican era. Conservatism, which seeks to occupy itself in the right politics in Turkey, attaches importance to preserving the historical experience and achievements and maintaining the achievements of the Turkish modernization.

The mass media play a central role in presenting a new way of life to individuals in the context of the cultural rationale of late capitalism, as consumption becomes a lifestyle. In developing countries such as Turkey, large masses are convinced to be consumers as much as possible through media and consumption habits are gained.

The products that meet the basic purpose requirements of the media are to present identities that will be identified with the values given to them together with their consumer products, and to purchase these artificial identities (Dağtaş \& Dağtaş, 2009, s. 65). While it is believed that conservatism often evokes an opposition to consumerism, it is not surprising that they both coexist. This partnership has similar benefits for both social perspectives and even brings them closer together as a relationship of interest.

The appearance of the Islamic female image in the public sphere dates back to the 1960s. After the beginning of the 1990s, with the political positions and economic empowerment achieved, the conservative woman has been "seen in the most elegant way" was basic concern. As a resulth this,the concept of fashion, and entartaiment has become available together with tesettur (Balkanlıoğlu, 2014, s. 13). 
After 1980, neo-liberal politics in Turkey led to the consequent economic relaxation and expansion of the capital to different social classes, a new conservative middle class with its own lifestyle and consumption practices. The image-based evaluation criteria of the public sphere is almost imperative to look modern and well-behaved for conservative woman who want to come to better places in business world.

In this context, this study was conducted in order to understand how the contents of medical/ aesthetic health programs, broadcasted on television channels, are received by female viewers who position themselves under a conservative identity and to understand consumption behaviors in this direction.

In modern society, health consumption is no longer a necessity, it is not any more well being; it's to look fit, to look good, to earn status, to claim as value. Of course, the role of the media can not be denied in the commodification of health in this respect. In this context, the influence of the spread of special television channels in particular can not be excluded.

Especially when the impact of new health consumption trends on secular /modern women is more easily observed by the public. The purpose of this research is what is the attitude of the conservative women towards these medical / aesthetic health programmes and this new understanding of consumption.

This study is an etnographic research about the perception of female audience, who identify themself as conservative, regarding medical/aesthetic television programmes. The methodology used in this study is a focus group that involves 7 females.

It has been observed that, no matter the well educated level and the awareness of that the audience has about the affect of mass media, when it comes to health, medical/aesthetic operations are prefered instead of conservative identity or religious references by rationalizing the consuming health products or services. In this study, findings were detected that In the face of these programmes, the conservative female audience sees herself as an active subject but inevitably can be positioned as passive subject. Participants rationalized this aspect of health which turned into a commodity in consumer society.

Thus the conservative women refer to religious references despite the internal conflicts that the boundaries of the social identity they are in.

Key words: Conservative female identity, Medical /aesthetic television programmes, Audiences researches, Focus group

\section{Giriş}

İletişim araçlarının tarihi çok eski olmasına karşın, bu araçların izleyici üzerindeki etkilerinin araştırılması 20. yüzyılın başlarında ilgi odağı olmaya başlamıştır. Bu ilginin en önemli nedenlerinden biri de artan kapitalist üretim anlayışında üretilen malın kitlesel alıcılara ulaştırılması kaygısı olduğu söylenebilir. Kitle iletişimi başlangıçta sadece gönderenden alıcıya genel mesaj iletimi süreci olarak düşünülüyordu; ancak günümüzde temel model konusunda yaşanan değişimler kitle iletişiminin, toplumdaki konumundan ve kurumsal karmaşıklığından kaynaklanan, farklı niteliklerini göz önüne almayı zorunlu kılmaktadır. Bu yaklaşımda, ilk zamanlar kitle iletişim kuramlarında "medyanın insanlara ne yaptığı" araştırılırken, izleyicilerin medyayı kullanım şekli ve mesajların yorumlanması ihmal edilmiştir. Zamanla aracın verdiği mesajın kitlenin üzerinde çok farklı etkisi olduğu, kitle iletişim modellerinin değişen yapısını oluşturarak; kültürel, yorumlayıcı, eleştirel yaklaşım modelleri geliştirilmiştir. Böylece kitle iletişim araştırmalarında temel sorunsalı "etkin/edilgen izleyici" tartışmaları oluşturmuştur.

Türkiye'de son on yılda tecrübe edinilen ekonomik rahatlama ve sermayenin farklı toplumsal sınıflara yayılması, kendine özgü bir yaşam tarzı ve tüketim pratikleriyle yeni muhafazakâr bir orta sınıfın yükselmesine kaynak oluşturdu.1980'li yıllarda neo-liberal politikalarla birlikte ekonomik yapıda meydana gelen değişme; toplumun tüketim alışkanlıklarının, görsel kültürünün ve mekânsal oluşumlarının da köklü bir şekilde 
değişmesine neden olmuştur. Küresel ekonomiyle bütünleşen Türkiye ekonomisi, küresel kapitalizmin ekonomik, sosyal ve kültürel değerlerini de Türkiye'de gündelik yaşama dâhil ederek sosyo-ekonomik ve kültürel yapıyı dönüştürmüştür (Korkmaz, 2009, s. 160).

Bu dönemde tüketim kültürü, muhafazakârlığın modern yaşam biçimlerine yaklaşmasını sağlarken, muhafazakâr ideoloji de tüketim kültürünün pratik işleyişine önemli bir katkı sunmaya başlamıştır. Tüketim ideolojisi tıpkı muhafazakârlık gibi toplumsal veya bireysel dönüşümün yüzeysel bir şey olarak kabul edilmesini ister. Diğer bir deyişle muhafazakârlığın modern dünyaya eklemlenme biçimleri tüketim kültürünün tehlikeli olmayan içeriğiyle gerçekleşmekte ve tüketim kültürü de muhteviyatındaki muhafazakâr yönelimle buna uygun bir zemin hazırlamaktadır.

Son yıllarda tıp belirgin bir şekilde ticari bir yatırım sektörü haline gelmiştir. Buna bağlı olarak, tıp alanında üretilen yeni teknoloji/hizmetlerin satılabilmesi, reklam ve halkla ilişkiler faaliyetlerinin artışını da beraberinde getirmiştir. Yazılı ve görsel medyada artan sağlık haber ve programları; toplumdaki hastalık endişesinin artmasına, daha çok doktora gitme ve devamında yanlış/gereksiz ilaç kullanımının artmasına temel oluşturmuştur.

Artan sağlık hizmet/ürünleri tüketiminin sonuçları, modern kimlikle tanımlanan kadında kamusal alanda rahatlıkla gözlemlenirken; son zamanlarda kamusal alanda görünürlükleri artan muhafazakâr kadının bu yeni tüketim anlayışına yaklaşımı merak konusu olmuştur.

İslamcı kadın imgesinin kamusal alanda belirişi 1960'lara kadar uzanmaktadır. 1960- 1990 yılları arasında muhafazakâr kadının mücahide, militan, misyoner ve eylemci karakteri ön plandadır. 1990'ların başından sonra ise elde edilen siyasi mevziler ve ekonomik güçlenmeyle birlikte muhafazakâr kadının temel derdi kamusal alanda "en şık şekliyle görünmek" olmuştur. Bu kadınların dönüşümleri sonucu; "tesettürle eğlence", "tesettürle şık kıyafet", "tesettürle moda" kavramları bir arada kullanılabilir hale gelmiştir(Balkanlıŏlu, 2014, s. 13). Türkiye'de son on yılda tecrübe edinilen ekonomik rahatlama ve sermayenin farklı toplumsal sınıflara yayılması, kendine özgü bir yaşam tarzı ve tüketim pratikleriyle yeni muhafazakâr bir orta sınıfın yükselmesine sebep olmuştur. Kamusal alanın imaja dayalı değerlendirme kriterleri iş hayatında daha iyi yerlere gelmek isteyen muhafazakâr kadınlar için modern ve bakımlı görünmeyi adeta zorunlu kılmıştır.

\section{1. İzleyici Araştırmalarına Genel Bakış}

Kitle iletişimi başlangıçta sadece gönderenden alıcıya genel mesaj iletimi süreci olarak düşünülüyordu; ancak günümüzde temel model konusunda yaşanan değişimler kitle iletişiminin, toplumdaki konumundan ve kurumsal karmaşıklığından kaynaklanan, farklı niteliklerini gözönüne almayı zorunlu kılmaktadır. Bu yaklaşımdailk zamanlar kitle iletişim kuramlarında "medyanın insanlara ne yaptığı" araştırılırken, izleyicilerin medyayı kullanım şekli ve mesajların yorumlanması ihmal edilmiştir.

Zamanla aracın verdiği mesajın, kitlenin üzerinde çok farklı etkisi olduğu kitle iletişim modellerinin değişen yapısını oluşturarak; kültürel, yorumlayıcı, eleştirel yaklaşım modelleri geliştirilmiştir. Kitle İletişim araştırmalarında, "etkin/edilgen izleyici" tartışmaları temel sorunsalı oluşturmaktadır.

Denis McQuail, kitle iletişim araçlarının etkilerini dikkate alarak, bu alanda yapılmış bulunan araştırmalara üçlü bir sınıflama uygulamaktadır(Tokgöz, 2015, s. 26)Bunlar:

Güçlü Etkiler Dönemi ( 1920-1940)

Sınırlı Etkiler Dönemi ( 1940-1960)

Tekrardan Güçlü Etkiler Dönemi (1960- ve sonrası)

Dünya savaşlarıyla yükselen propaganda faaliyetleri ve Amerikan pozitivist deneyci gelenek tarafından başlatılan etki araştırmaları, izleyiciyi yalnızca sunulanı alan ve yönlendirilen edilgen bireyler olarak görme 
eğilimindedir. Bu anlayış 1940’lı yıllara kadar etkinliğini korumuştur. Öte yandan Lazarsfeld ve arkadaşları tarafından özellikle Amerikan başkanlık seçimleri döneminde yapılan çalışmalar iletişim araştırmalarına yeni bir soluk getirmiştir. İki aşamalı akış modeliyle, doğrusal ve tek boyutlu iletişim anlayışı gücünü yitirmiştir. 1960'larda Kullanımlar ve Doyumlar modelinin ortaya atılmasıyla, izleyiciye biçilen edilgen rol yerini etkin, mesajları yalnızca alan değil, yorumlayan, kullanan ve hatta içeriğine müdahale edebilen bir konuma yükseltmiştir(McQuail \& Windhal, 1997).

Güçlü etkiler dönemi olarak adlandırılan 1920-1940'lı yıllarda kitle iletişim araçlarının (gazete, radyo) etkilerinin güçlü olduğu kabul edilmektedir. Bu dönem itibariyle; Sihirli Mermi (Magic Bullet), Su Şırıngası (Hypodermic Needle), Aktarma Kemeri (Transmission Belt) gibi kuramsal yaklaşımlar devrededir. Bu dönemde genel yaklaşım, kitle iletişim araçlarında gönderilen iletininbireyi bularak birey üzerinde büyük etkiler bıraktığı yönündedir. Bu bağlamda kabul görülen iletişim doğrusaldır. Bir kaynak vardır, mesaj ve bir de mesajın yönlendirildiği hedef vardır. Bu iletişim modellerinde Almanya'da Hitler'in yapmış olduğu propaganda çalışmalarının etkileri olduğu söylenebilir.

1940-1960'। yıllara gelindiğinde ise kitle iletişim araçlarının verdiği mesajların izleyici/dinleyici/okur üzerinde o kadar da büyük bir etkisi olmadığı kabul edilen Sınırlı Etkiler Dönemi'dir. Bu dönemde yazılı basın, radyonun yanı sıra televizyonunda devreye girdiği görülmektedir. Sınırlı Etki Modeli, daha çok iletişim endüstrisine ve iletişimi üretenlere destek vermekteydi. Bu sorunun çözümü olarak Kullanım ve Doyumlar yaklaşımı geliştirildi. Katz 1959'da “iletişim araçlarının halka ne yaptığından” çok "Halkın bu araçlarla ne yaptığına" dikkat edilmesi gerektiğine ve Klapper Kullanım ve Doyumlar yaklaşımının gelişmesini "Halk kitle iletişimi ile ne yapıyor?" şeklindedeğiştiğini söyler(Tokgöz, 2015, s. 283).

Amerika'da pozitivizmin etkisiyle nesnel veriler toplamak amacıyla yapılan alan araştırmaları, medyanın sanıldığı gibi güçlü etkilere ya da ikna gücüne sahip olmadığını bulgulamışlardır. Dönemin araştırmacılarındanHovland'ın askerler üzerine uyum sağlamaya yönelik yaptığı çalışmalar, medyanın bilgi iletmede etkili olurken tutumları değiştirmede etkili olmadığını ortaya çıkarmıştır(Werner ve Tankard'an aktaran:Cangöz, 1999).

Alan araştırmaları sonuçları ışığında güçlü etkiler döneminin kabullenimleri terk edilirken, bireyler arası iletişimin yeni keşfedilen gücünü vurgulayan kuramlar ağırlık kazanmıştır. Bu döneme yön verenler Kurucu Babalar (Founding Fathers) Wilbur Schramm'a göre: Harold D. Laswell, Paul F. Lazarsfeld, Kurt Levin ve Carl Hovland'dır(Tokgöz, 2015, s. 103).Yine bu dönemde Lazarsfeld ve ekibinin yaptığı seçim araştırmaları ise az sayıda kişinin seçim kampanyaları süresince yürütülen iletişim kampanyalarından etkilendiğini gözlemlemişlerdir.

1960 yılından sonra ise kitle iletişim araçlarının güçlü etkilerinden tekrar söz edilmeye başlanmıştır. David Morley bu durumu "...from "effects" to "functions"...and back again" olarak yorumlar(Morley, 1992, s. 44). Bu dönemde televizyon izleyici üzerinde artık daha etkindir. Televizyon izleme sürecinde izleyicinin edilgen bir alıcı olduğu düşüncesi 1960'lardan sonra değişmeye başlamıştır. İzleyicilerin kitle iletişim araçlarını etkin bir şekilde kullandığını iddia eden "Kullanımlar ve Doyumlar" yaklaşımı işlevselci perspektiften bakarak izleyicilerin televizyonuneden izledikleri sorusuna cevap aramaktadır(Aydın, 2007, s. 119-131). Televizyon izleyicisinin, ekranda verilen her mesajı almadığını ve televizyon karşısında edilgen bir özne olmadığını ilk defa Kültürel Çalışmalar ortaya atmıştır.

Ama 1970 'li yıllarla birlikte medyanın güçlü etkileri bakımından yeni kuramsal yaklaşımların arka arkaya devreye girdiğini söylemek gerekir. Bunlar: Gündem Koyma Kuramı (Agenda Setting Theory), Medya Sistemleri Bağımlılı̆ı Kuramı (Media System Dependancy Theory- Melvin Defluer, Sandra Ball-Rokeach,1975), Bilgi Gediği Kuramı (Knowledge Gap; P.J. Tichenor, G.A. Donohue, C.N. Olien, 1970) (Tokgöz, 2015, s. 287).

Stuart Hall, "Kodlama-Kodaçımlama (coding-encodding) öncü çalışmasıyla, izleyici araştırmalarına yeni bir bakış kazandırmıştır.Hall, mesajların birden fazla anlamlandırma içerdiği sürece, medya mesajlarının izleyici 
tarafından müzakereci bir şekilde okunduğunu belirtir. Hall, televizyon mesajlarının oldukça karmaşık bir yapıya sahip solduğunu ve bu mesajların sessel ve görüntüsel olmak üzere iki türlü söylemi içerdiğini söyler(Morley, 1992, s. 47). Hall, ideolojik alanın televizyon aracılığıyla kurulduğu ancak çoklu okuma ya da eleştirel yorumlarla bu alanın tehdit edildiğine vurgu yaparak, izleyicinin edilgen özneden aktif özneye geçtiğini söylemektedir.

Ayrıca Hall izleyici, medya söylemini toplumsal pratiklerin dolayımıyla belli bir dönüşüm ile okuduğunu söylemektedir. Eğer izleyici belli bir toplumsal pratik dolayımıyla anlam oluşturamıyorsa haber tüketilemiyor demektir. Bu durumda herhangi bir etkiden söz edilemez(Tokgöz, 2015, s. 56). İzleyici araştırmalarının önde gelen ismi David Morley ise, kitle iletişim araştırmalarında temel olarak Everyday Television: Nationwide, The Nationwide Audienceve Family Television adlı çalışmalarıyla izleyici alınlamasına yönelik yaklaşımlarda önemli açılımlarda bulunmuştur. Morley'e göre izleyici artık atomize olmuş bireylerin oluşturduğu edilgen kitle olarak değil; mesajların okunmasında aktif olabilen, medya mesajlarının açımlamasında ortak kültürel yönelimleri paylaşan üyelerin oluşturduğu alt sosyal/kültürel gruplardır(Cangöz, 1999, s. 57).

\section{Muhafazakâr Kadın ve Tüketim Kültürü}

Muhafazakârlığın kelime olarak doğuş kökenine bakılacak olursa, "muhafazakârlık" kökeni Latince olan "Conservare" kelimesinden türetilmiş ve Fransızca Conservatuer kelimesinden dünyaya yayılmıştır. Arapça'dan Türkçe'ye geçen muhafazakârlık "ha-fe-za" kelimesinden türetilmiştir. Buradaki anlamı ise "korumak, bellekte tutmak ya da olduğu gibi muhafaza etmek" anlamlarına gelmektedir(Marshall, 1999, s. 512). Fransızca Conservatuer kavramıla vurgulanan husus ise mirasınkorunması, toplumsal hafızanın diri tutulması yani sürekliliktir.

Günlük dildeki "muhafazakâr" kavramı, farklı anlamlara sahiptir. Bu kavram mütevazı veya ihtiyatlı davranış, geleneksel hatta uyumcu bir hayat tarzı, değişim korkusu veya değişimin reddi gibi özellikle "muhafaza etmek" fiilinin belirttiği anlamlara gelebilir. Kısacası, muhafazakâr düşünce ve muhafazakâr siyaset; Rönesans ve Reform hareketleri ve bunun sonrasında Aydınlanma düşüncesine karşı eleştirel bir tavır olarak ortaya çıkmıştır. Fransız Devrimi'nin ilkelerine karşı reaksiyoner bir yapı sergilemiş ve Sanayi Devrimi sonrasında belirginleşen kapitalist sınıf yapısına ve evrenselliğe karşı çıkma hareketleriyle şekillenmiştir(Türköz, 2011, s. 9).

Muhafazakârlık açısından kültür, geleceği değil, geçmişi simgelemektedir. Bu geçmiş imgesi içerisinde estetik kimi değerler ve yapılanmalar olduğu kadar, gündelik yaşamın geleneksel sıradan biçimleri de yer almaktadır. Muhafazakârlığın ortaya çıkışı modernitenin ve modernleşme süreçlerinin ortaya çıkışıyla ilgilidir ve modernleşme ile olan karşıtlık bağlamında şekillenmiş bir ideoloji ve doktrindir. Bu nedenle muhafazakârlık modernliğin karşıtı olarak algılanır(Yücebaş, 2013, s. 8,18).

Muhafazakârlık, aydınlanma aklının mutlaklığına karşı tecrübe ve deneyime vurguyapan, dine vermiş olduğu referanslarla ön plana çıkan, ailenin, tarihin özellikle de geleneğin önemine dikkat çeken, serbest piyasa ekonomisini destekleyen, bireysel haklar savunucusu olduğunu iddia eden ancak, sınırsız özgürlüklere karşı çıkan, devletin ekonomik hayata ve topluma olan etkisinin azaltılmasından yana olan modern siyasi bir ideolojidir.19. yüzyıldaki klasik, radikal nitelikli Fransız ve Alman muhafazakârlığı karşısında İkinci Dünya Savaşı sonrasında evrimci, bireyci, katılımcı, serbest piyasacı niteliklere dönüşen yeni muhafazakârlık (neomuhafazakârlık) ortaya çıkmıştır. 1980 sonrasında ise muhafazakârlık bugünkü liberalizme yakın bir çizgiye ulaşmıştır.

Türkiye'de ise muhafazakârlık, Cumhuriyet dönemiyle birlikte ortaya çıkmıştır. Türkiye'de sağ siyaset yelpazesinde kendine yer edinmeye çalışan muhafazakârlık, tarihsel tecrübenin ve kazanımların korunmasına ve Türk modernleşmesiyle elde edilenlerin sürdürülmesine önem vermektedir. Türk Modernleşmesi kapsamında başlangıçtan itibaren kendine alan açmaya çalışan muhafazakâr düşünce, 1950'li yıllarda hız kazanarak günümüze kadar ulaşmayı başarmıştır.24 Ocak Kararları ve Turgut Özal döneminde doğan ve serpilen Anadolulu İslami Burjuvazinin hızı 28 Şubat'la kesilmeye çalışılmıştır. Kısa süreli bir durgunluk olsa da 2002 yılında Adalet ve Kalkınma Partisi'nin (AKP) iktidara gelmesi ile bu kesim büyüme hızını da sürekli artırmıştır. 
Kişiselleştirme doğallaşmanın, işlevselleşmenin ve kültürlüleşmenin çağdaşıdır. İnsanlar arasındaki gerçek farklııkları kaldırarak, kişileri ve ürünleri türdeşleştirerek aynı zamanda farklılaşmanın saltanatını da başlatan şey tekelci endüstriye yoğunlaşmadır(Baudrillard, 2004, s. 105). Tüketilen şeyler arasında diğer nesnelerden daha güzel, daha kıymetli, daha eşsiz bir nesne vardır; bu da bedendir. Bin yıllık bir püritanizm çağından sonra fiziksel, cinsel özgürleşme biçiminde bedenin yeniden keşfi ve reklamda, modadave kitle kültüründeki mutlak varlığı bedenin etrafını kuşatan sağlık, perhiz, tedavi kültü, gençlik zariflik, erillik/dişilik saplantısı bedenle ilgili bakımlar, rejimler bedeni kuşatan arzu söylemi bunların hepsi bedenin günümüzde kurtuluş nesnesine dönüştüğünün tanığıdır. Beden bu ahlaki ve ideolojik işlevde tam anlamıyla ruhun yerini almıştır(Baudrillard, 2004, s. 163).

1980'li yıllarda neo-liberal politikalarla birlikte ekonomik yapıda meydana gelen değişme, toplumun tüketim alışkanlıklarının, görsel kültürünün ve mekânsal oluşumlarının da köklü bir şekilde değişmesine neden olmuştur. Küresel ekonomiyle bütünleşen Türkiye ekonomisi, küresel kapitalizmin ekonomik, sosyal ve kültürel değerlerini de Türkiye'de gündelik yaşama dâhil ederek sosyo-ekonomik ve kültürel yapıyı dönüştürmüştür(Korkmaz, 2009, s. 160).Türkiye'de "tüketim toplumu" ya da "tüketim kültürü" olguları, özellikle 1980'li yıllardan başlayarak adından sıkça söz edilen kavramlar olmuştur.

Tüketim olgusunun bir yaşam tarzına dönüşmesinde yeni yaşam tarzının, geç kapitalizmin kültürel mantığı çerçevesinde bireylere sunulmasında kitle iletişim araçları merkezi bir rol oynamaktadır. Türkiye gibi gelişmekte olan ülkelerde, medya aracılığıyla geniş kitleler mümkün olduğunca tüketici olmaya ikna edilmekte ve tüketim alışkanlıkları kazandırılmaktadır. Medyanın buradaki temel amacı gereksinimlerini karşılayacak ürünleri sağlamaktan öte, onlara tüketim ürünleriyle birlikte verilen değerlerle özdeşleşecek kimlikler sunmak ve bu yapay kimliklerin satın alınmasını sağlamaktır(Dağtaş \& Dağtaş, 2009, s. 65).

Muhafazakârlığın çoğunlukla tüketim kültürüne yönelik bir karşıtlığı çağrıştırdığına inanılsa da ikisinin bir arada bulunması şaşırtıcı bir durum değildir. Bu ortaklığın her iki toplumsal perspektif için benzer faydaları bulunmakta ve hatta bir çıkar ilişkisi olarak her ikisini birbirine yakınlaştırmaktadır. Tüketim kültürü muhafazakârlığı modern yaşam biçimlerine yaklaşmasını sağlarken, muhafazakâr ideoloji de tüketim kültürünün pratik işleyişine önemli bir katkı sunmaktadır. Tüketim ideolojisi tıpkı muhafazakârlık gibi toplumsal veya bireysel dönüşümün yüzeysel bir şey olarak kabul edilmesini ister. Her ne kadar ikisi arasında çatışmalı bazı durumlar söz konusu olsa da bu bir arada bulunabilme halinin tarihsel bir gerçekliği de bulunmaktadır(Yücebaş, 2013, s. 92).

İslamcı kadın imgesinin kamusal alanda belirişi 1960’lara kadar uzanmaktadır. 1960-1990 yılları arasında muhafazakâr kadının mücahide, militan, misyoner ve eylemci karakteri ön plandadır. 1990'ların başından sonra ise elde edilen siyasi mevziler ve ekonomik güçlenmeyle birlikte muhafazakâr kadının temel derdi kamusal alanda "en şık şekliyle görünmek" olmuştur. Bu kadınların dönüşümleri sonucu; "tesettürle eğlence", "tesettürle şık kıyafet", "tesettürle moda" kavramları bir arada kullanılabilir hale gelmiştir(Balkanlıoğlu, 2014, s. 13).

Handan Karakayadoktora çalışmasında, Cumhuriyet elitlerinin karşısında modernliğin dili üzerinden alternatif bir modernliğin temsilcisi olan muhafazakâr/dindar üst kadın sınıfının, 2000'lerden sonra kentli elitlerle daha çok benzerlikler taşıyan bir tüketim ve yaşam anlayışını benimserken, bunun eleştiri ve meşruiyet kriterlerini de kendi içinde tartışmakta olduğunu söylemektedir. Karakaya, doktora tezi sırasında kendini muhafazakâr/dindar olarak tanımlayan kişilerle yaptığı görüşmede, özellikle 2000'li yılların ikinci yarısından sonra bu muhafazakâr kesimden daha çok kadınların hayatında köklü değişikliklerin olduğunu belirttiklerini ifade etmektedir. (Karakaya, 2015, s. 201,225)

“Nitekim kendileriyle değişen tüketim pratikleri ve yaşam biçimleri üzerinde konuştuğumuz kadınların önemli bir kısmı İslam dininin iyi giyinme ve iyi yaşama konusunda olumsuz bir tutumunun olmadığının altını çizmeye çalışmıştır. Bunun yanında verdikleri zekât ve sadakanın da tüketim pratiklerini dini değerler 
bağlamında meşrulaştırdığı düşüncesindedirler. Bu düşüncenin de beraberinde hayatın tüm yönlerini içine alan bir yaşam pratiğine muhafazakâr/dindar burjuva ve kadınlar üzerinden yaşam alanı açtığı düşünülebilir"

Türkiye'de son on yılda tecrübe edinilen ekonomik rahatlama ve sermayenin farklı toplumsal sınıflara yayılması, kendine özgü bir yaşam tarzı ve tüketim pratikleriyle yeni muhafazakâr bir orta sınıfın yükselmesine sebep olmuştur. Kamusal alanın imaja dayalı değerlendirme kriterleri, iş hayatında daha iyi yerlere gelmek isteyen muhafazakâr kadınlar için modern ve bakımlı görünmeyi adeta zorunlu kılmıştır.

Abraham Maslow'un intiyaçlar hiyerarşisi teorisinde her ihtiyaç kategorisinde ayrı bir kişilik gelişme düzeyinin var olduğu ve bireylerin bir alt kategoride tanımlanmış intiyaçları tam olarak gidermeden bir üst kategorideki ihtiyaçların kişiyi tatmin edemeyeceğini ve kişiliğin gelişiminin sekteye uğrayacağını ileri sürmektedir(Şahin, 2009, s. 106).Orta-üst sosyo-ekonomik statüde yer alan muhafazakâr kadın, medyanın her gün yeniden üreterek metalaştırdı̆̆ı ve "yapmaz ise eksik hissedeceği” bedenin güzelleşmesini, Maslow'un ihtiyaçlar hiyerarşisinin dördüncü basamağında yer alan "saygınlık gereksinimi" bağlamında rasyonelleştirerek tüketecektir. Kadın konusu, tarihsellikten gündelik yaşama uzanan toplumsal dönüşümün en ayrıcalıklı konusudur. Çünkü kadın, bir yandan altında bir medeniyet projesi yatan tarihsel dönüşümün, diğer yandan cinsiyet ayrımcılığı üzerine kurulu İslami toplumsal yapının en önemli mihenk taşıdır (Göle, 2014, s. 170). Kadınlığa dair inşa edilen ideolojik gündemin, dış görünüşle aşırı ilgilenmesi ve erotik güzellik ideali ataerkil cinsel söylemin ve kadınlar üzerindeki cinsel baskının bir uzantısıdır(Özdemir, 2009, s. 234).

\section{Medikal Estetik Televizyon Programlarının Muhafazakâr Kadın İzleyici Alımlaması}

\section{1. Çalışmanın amacı}

Bu çalışma televizyon kanallarında yayınlanan medikal/estetik konulu sağlık program içeriklerinin, kendini muhafazakâr kimlik altında konumlandıran kadın izleyiciler tarafından nasıl alımlandığı ve bu yöndeki tüketim davranışlarını anlamak amacıyla yapılmıştır.

Özellikle 1980 sonrası Türkiye ekonomisinde meydana gelen yeni tüketim anlayışı, kendini sağlık hizmetleri ve ürünlerinin tüketiminde de etkin şekilde göstermiştir. Sağlık tüketimi artık bir ihtiyaç, bir iyilik hali için değil; fit görünme, güzel görünme, bir statü elde etme, bir değer olarak talep görmeye başlamıştır. Sağlığın bu şekilde metalaşmasında elbette ki medyanın rolü yadsınamaz. Bu bağlamda özellikle özel televizyon kanallarının yaygınlaşmasının etkisiyle de medikal/estetik programları günlük yaşamımızın tam ortasına düşmüştür. Özellikle yeni sağlık tüketim eğilimlerinin seküler/modern kadın üzerindeki etkisi toplum tarafından daha rahatlıkla gözlemlenirken, araştırmacıyı düşündüren muhafazakâr kadının bu medikal/estetik sağlık programlarına ve bu yeni tüketim anlayışına yönelik tavrının ne olduğu yönündedir.

\subsection{Yöntem}

Etnografik araştırmalar, bir grubun davranışını doğrudan gözlemleyerek ve bu gözleme dayanarak grubailişkin bir betimleme yapmak olarak tanımlanan, kaynağını antropoloji ve beşerî bilimlerden alan ve daha çok nitel analizlere dayanan bir araştırma tekniğidir. Medyanın etkisini doğal tüketim ortamından soyutlayarak ölçmeye çalışan araştırmaların sınırlı bir etkiyle karşılaşacaklarını belirten Morley, medyanın etkilerini ölçmede tümlüklü yöntemin etnografi olabileceğini savunmaktadır(Werner ve Tankard'an aktaran:Cangöz, 1999, s. 58).

Araştırmacı, çalışmayı etnografik yöntemle fokus grup üzerinde yapmaya karar verdiğinde, katılımcılarla“sağlık programlarının kadınlar üzerinde alımlamasına” yönelik bir çalışma yaptığını ve katkıda bulabilecekler mi? diye sorduğunda önce tereddütsüz olumlu cevap veren gönüllüler; sonrasında bu çalışmanın "muhafazakâr kadın kimliği" alt başlığı altında irdeleneceğini öğrendiklerinde daha önce gönüllü olanların çekimser davrandıkları gözlemlenmiştir. Burada "muhafazakâr" kelimesi telaffuz edildiği anda tüm katılımcıların bir "ötekileştirme" duygusuna kapıldıkları ve araştırmacının tamamen "kendileri hakkında bir önyargıyla" konuyu araştıracağı duygusuna kapıldıkları dikkat çekecek şekilde gözlemlenmiştir. Bu bağlamda çalışma, önce tüm grup üyeleri ile yapılan yüz yüze, güven inşa eden mülakatlar sonrası yapılandırılmıştır. Bu durum da bu çalışmanın bir diğer sınırlılıklarında birisidir. 
Çalışmamızda kendini muhafazakâr kimlikle tanımlayan (başı kapalı, beş vakit namaz kılan, oruç tutan, vb.)7 kadın izleyici ile katılımcı gözlem ve anket tekniğikullanılarak yapılmıştır. Araştırmaya katılanların yaş aralığı 27-45, yaş ortalaması ise 35,7 olarak tespit edilmiştir. Çalışmanın amacına uygun olarak, araştırmanın öznesi kadın cinsiyeti ile sınırlandırılmıştır. Araştırmaya katılan kadınların:5'i evli ve çocuklu 2'si bekâr; eğitim durumları2'si doktora, 2'si yüksek lisans öğrencisi olup, 2 lisans ve 1 ön lisans.Katılıcıların 6’sı kendini "muhafazakâr" olarak tanımlarken yalnızca biri "milliyetçi-muhafazakâr" kimliğine vurgu yapmıştır. Tüm katılımcılar kendilerini sosyo-ekonomik statü olarak orta ve orta-üstü olarak konumlandırmışlardır (kendine ait evi- arabası var, vb.).

Çalışmanın yapıldığı fokus grubun en önemli özelliğinin ise tüm katılımcıların "sağlık yönetiminde" aktif olarak çalışıyor olmaları ve aynı zamanda eğitimlerinin de (lisans ve lisanüstü) yine bu alanda toplanmış olmasıdır. Araştırmacı katılımcıların bütün bu özelliklerini bilmesine karşın, bu tür programların alımlamasında, arka plandayer alan eğitimin etkisinden çok, muhafazakâr kimliği, alımlamada ve program tüketimi bağlamında konuyla bağlantılandırmıştır. Ama yine de çalışmada katılımcıların eğitiminin, alımlamaya etkisini yadsınamaz. Fakat bu çalışmada başat etken olarak değerlendirilmemiştir.

Çalışma zaman ve mekân sınırlaması altında gerçekleştirilmiştir. Katılımcıların çalışma mekânında, gündüz kuşağı programlarının evde izlenen atmosferine uygun hale getirilmiş (çay, börek, kuru pasta ve sohbet ortamı sıcaklığında) öğlearası (12:00-13:30) toplantı salonunda yapılmıştır.Katılımcılara izletilen program: Grubun sosyal kimliğine (muhafazakâr) uygun olarak belirlenen, kendini muhafazakâr kanal olarak tanımlayan TVNet Televizyon Kanalı'nda yayınlanan “Sağlık Raporu”programı tercih edilmiştir.Sağlık Raporu Programı, TVNet Televizyon Kanalı'nda hafta içi her gün canlı olarak sabahları 08:15'de başlamakta ve programsunucusu Ayşenur Asuman Uğur'dur. Fokus grup ile yapılan çalışmada, sağlık programının 18 Mart 2015 tarihinde yayınlanan ve yaklaşık 32 dakika süren program banttan izletilmiştir.Programa bir özel hastane olan Medikal Park Hastaneler Grubunun Bahçelievler Hastanesi'nde Estetik ve Plastik Cerrahı Op. Dr. Esra Bilgen katılmaktadır.Programda: "Estetiğe bakış" genelkapsayıcı başlık altında; toplumda oluşan estetik algısı, son zamanlarda gerek kadınlarda gerekse erkeklerde oldukça öne çekilen estetik operasyon yaptırma yaşları ve bunun sağlık/tüketim toplumu yönünde oluşan gerekçeleri. Burun, Yüz gençleştirme ve meme estetik operasyonları konuşulmaktadır.

Program, hafif sakinleştirici bir müzik altyapının yer aldığı; "teşhis, tedavi, koruyucu sağlık, sağlık politikaları" yazılı sloganları beyaz önlük içerisinde kadın/erkek doktor olduğu düşünülen ve göz muayenesi, tansiyon ölçme gibi görsellerle zenginleştirilmiş fakat tamamen piyasalaştırılmış bir sağlık değilde daha yapıcı, kamu politikalarını önceleyen bir duygu oluşturan jenerikle başlamaktadır.

\section{3. İzleyicinin değerlendirilmesi}

Çalışma, araştırma grubuna daha önce bildirilen 10 Mayıs 2016 tarihinde, tüm katılımcıların çalışma mekânında yer alan bir toplantı salonunda gerçekleştirilmiştir. Program gruba izletilmeden önce bir kez daha çalışmanın içeriği ve amacı grup üyeleri ile paylaşılmıştır. Grubun,programı izlemeye başladıkları ilk 7-8 dakika oldukça sessiz, dikkatli bir şekilde, çaylarını sessizce yudumlayıp, çekimser bir yüz ifadesi eşliğinde konuğu ve sunucuyu tartan bir dikkatle izledikleri gözlemlenmiştir.

Sağlık, hizmet sunucusu ve tüketicisi arasında bilgi asimetrisinin en güçlü olduğu alandır. Bu bağlamda özellikle sağlık programlarında çıkan konuğun güvenirliği de izleyici tarafından sorgulanabilmektedir. Konuğun güvenirliği izleyici bakımında önemli olduğu, sonuçta estetik gibi geri dönüşü olmayan bir tercih yaptıkları için konuk ile ilgili ilk reaksiyonu (Katılımcı 7) verdi. "Bu çok genç ben buna olmam..." Şeklindeki itiraza, diğer grup üyeleri pek katılmadıklarını aynı fikirde olmadıklarını çeşitli gerekçelerle ifade ettiler.

(Katılımcı 6) "Belki beceriklidir."

(Katılımcı 4) "Genç, ama belki el becerisi vardır." 
Grup üyeleri, formal eğitimlerinden bağımsız olmayarak, bir ön kabulle programa ve içeriğine yaklaşmışlardı.Sağlıkalanında farkındalığı oldukça yüksek bir grup olduğundan, programı izlerken bu tür programların bilgilendirme yönünden çok, çıkan konuğun özellikleri ve temsil ettiği sağlık kurumu dikkatlerini çekmiştir. Program, tamamen Medikal Park Hastanesi'nin reklamına yönelik olduğunun ve özellikle "kadın" bir plastik cerrahının programa konuk olması ve kanalın hedef kitlesine uygun olan muhafazakâr kadınlarına yönelik bir pazarlama stratejisi olduğu, ön kabulüyle grubun programı izlediğigözlemlenmiştir. Bu tür programların tüketime yönelik olduğuna dair iddialara yönelik olarak;

(Katılımcı 1) "Bilgi sahibi oluyoruz yine de."

(Katılımcı 3) "Bilinçli kesim olarak biz 'hekimin ve hastanenin reklamı daha çok yapılıyor', ön kabulüyle programı izledik."

Her ne kadar, eğitimli ve bu alanda yüksek bilince sahip bir grup olsa da ve sağlık söz konusu olduğunda, estetik operasyonun tercihi muhafazakâr kimliğin veya dini referansların önüne geçtiği gözlemlenmiştir.Katılımcılar, Sağlık gibi gerekçelerle daha çok tüketim toplumuyla bir meta dönüşen sağlığın bu tarafınırasyonelleştirmişlerdir.

(Katılımcı 7) "Sağlık açısındaysa bence olabilir."

Konuk doktorun "Herkesin ameliyat olma hakkı vardır," söylemine;

(Katılımcı 5) "Muhafazakâr kimlikle tanımlıyorsak bir de şunu söylemek lazım; caiz midir hocam? Bizim ilk sormamız gereken bu olacaktır, "haktan" önce."

Grubun tüm üyeleri bu cevaba gülerek eşlik etmişlerdir.

Araştırmacı "O halde estetik dinen caizdir," şeklinde tartışmaya müdahale edince;

(Katılımcı 2) “O şekilde değil” diyerek, şiddetli bir şekilde beden dilinin de eşliğinde itiraz etmektedir.

(Katılımcı 5) "Bu konuda fetva çıkaramayız"

(Katılımcı 3) "Diyanetin fetvaları şöyle; fıtrata uygun ise olumlar. Estetiğe muhafazakâr olarak radikal şekilde bakmanın bir anlamı yoktur. Dinimiz kolaylık dinidir. Bu bir tercihtir."

Katılımcı grupta gözlemlenen bir diğer önemli husus da her ne kadar muhafazakâr kadın kendini mutlu etmek, öz saygısını kazanmak için estetik ameliyatları yaptırıyor görüşü yüzeyde yaygın olarak gözlemlense de temelde, "erkeğini-eşini” memnun etmek için bu tür operasyonları olumlu baktıkları izlenmiştir.

Sunucu İnsanlar estetiği kendisi için mi yaptırıyorlar, yoksa başkası için mi?" diye uzman konuğa sorduğunda;

O ana kadar sessiz bir şekilde izleyen (Katılımcı 2), hemen başını sallayarak, adeta sonucunun uzman konuğa çok yerinde bir soru sorduğu ve kendisinin de sanki aklında cevap arayan böyle bir kaygısı varmış gibi olumlar şeklinde başını sallamıştır.

(Katılımcı 7) "Kişi kendisi için değil, karşısındaki için yapıyor. Kendisini beğendirmek istediği eğer beğenmezse ters tepiyor."

(Katılımcı 3) Baş işaretiyle doktorun söylemini onaylayarak "kendi ruhu için” diyor.

(Katılımcı 7) "Karşıdaki kişi için yaptırıyor, Karşıdaki kişinin tepkisi, onu besliyor, bence öyle. Bana sen desen ki ne kadar güzel olmuş (parmağıyla burnunu göstererek-bu arada katılımcı daha önce sağlık nedeniyle rinoplasti- 
burun estetik ameliyatı- geçirmiş.) dersen, o beni besler. Benim beğenip, beğenmemem önemli değil, önemli olan karşıdakinin tepkisi..."

(Katılımcı 3) "Tesettürlü olmak veya olmamak değil konu, artık sezaryen ameliyatlarında dahi estetik dikiş istiyoruz. Kendisine saygısı olan her kes, her şeye dikkat ediyor. Etmek zorunda hissediyor"

(Katılımcı 6) “Meme estetiği eşi mutlu etmek için yapılabilir, 'adam başka yere gider mi diye' kaygı vardır."

(Katılımcı 2) "Kaşlarımı almam, saçlarımı boyamam. Şu anda beyazlarım var. Ama ileride eşim isterse yaparım. Evde her türlü sınırlarımı aşarım."

(Katılımcı 7) “Dini görevlerimizden biri de eşine güzel görünmek. İronik bir şekilde, "Gözü dışarı kaçmasın.”

(Katılımcı 5) "Evdeki erkekteki bu algıyıdeğiştiren bu tür programlar" diyerek, özelde bu tür programlara genel de ise medyanın bu yöndeki olumsuz tarafına dikkati çekmiştir.

Günümüz tüketim toplumlarında, tüketim intiyaçtan çok prestij, farklılık, bir gruba aidiyet, kimlik ve imaj edinme sınıf atlama gibi simgeler adına yapılmaktadır. Medya içerikleri, tüketiciye metaları kullanarak sınıf atlayacağı, yaşamının olumlu anlamda değişeceği, bir gruba ait olacağı ya da farklı olacağı türünde iletiler sunmaktadır(Dağtaş \& Dağtaş, 2009, s. 7).

(Katılımcı 3) "Medya artık kadın/erkeğin güzel olması fikrinde yeni nesli yapılandırıyor. Artık her erkek yataktan kalkan eşinin makyajlı, fönlü olmasını arzu ediyor. Dizilerde bu şekilde veriliyor. Ev içindeki beklentide bu yönde değişiyor." Değişen bu tüketim alışkanlığını bir önceki kadın kuşakla bağlantılandıran katılımcı, "Artık evde annelerimizden daha fazla özenli giyiniyoruz" diye ekliyor.

Eleştirel okuma yapan izleyiciler, programların farklı okumalarını yapabilmekiçin farklı yorumlama çerçeveleri oluştururlar. Programların birer kurgu-inşa olduğunun bilincindedirler. Yapım hilelerinin zaman ve bütçesinin programlarınoluşturulmasındaki etkisinin farkındadırlar(Rahte, 2013, s. 21).Sağlık alanında farkındalığı oldukça yüksek bir grup olduğundan, programı izlerken bu tür programların bilgilendirme yönünden çok, çıkan konuğun özellikleri ve temsil ettiği sağlık kurumu dikkatlerini çekmiştir. Program tamamen Medikal Park Hastanesi'nin reklamına yönelik olduğunun ve özellikle "kadın" bir plastik cerrahının programa konuk olması ve kanalın hedef kitlesine uygun olan muhafazakâr kadınlarına yönelik bir pazarlama stratejisi olduğu yönünde grup üyelerinin hem fikir oldukları gözlemlenmiştir.

Programda konuk uzmanda bunun farkında olup sürekli olarak kadın hastalar için "hanım" kelimesini kullanarak hitap ediyor. Kesinlikle "kadın" hasta demiyor. ${ }^{2}$ Bu tür programların tüketime yönelik olduğuna dair iddialara yönelik olarak;

(Katılımcı 3) "Bilinçli kesim olarak biz hekimin ve hastanenin reklamı daha çok yapılıyor, ön kabulüyle programı izledik"

(Katılımcı 1) "Bilgi sahibi oluyoruz yine de."

Etnografik yöntemde özellikle fokus grup çalışmalarında, grup üyelerinin sembolik (mimik ve jestleri) reaksiyonlarından çok sözsel reaksiyonları araştırmacı için daha nesnel nitelikler taşımaktadır.

Çalışmanın bu ilk sessiz dakikaları araştırmacıyı, kendi içinde sessiz bir kaygıya itmiştir. Sunucunun, "Doktor tercihinde nasıl hasta jinekolojide kadın hekim talep ediyorsa, estetik cerrahide de tercih edebilir" şeklindeki sözüne ilk reaksiyonu (Katılımcı 5) "Tabi ki silikonu taktıranlar daha çok kadın tercih ederler"

\footnotetext{
${ }^{2}$ Muhafazakâr kesim "hanım" hitabını "kadın" söylemine tercih ediyor. "Hanım” hitabını daha anaç, gelenekçi olarak kabul görürken, "kadın" söylemi daha seküler olarak anlamlandırılmaktadır.
} 
ifadesiyle, böylece gruptaki o sessizliği kırıp, grubun programı izlemede daha katılımcı/etkin olmasını sağlamıştır.

İletişim çalışmalarında "üçüncü kişi etkisi” olarak ifade edilen hipoteze göre insanlar medya içeriklerinin diğer kişileri kendilerinden daha fazla etkilediği düşüncesi yer almaktadır(Aydın, 2007, s. 121). Çalışmada (Katılımcı 5) kendisinin bu alanda bilgili olmasına rağmen kaynanasının televizyonda çıkan tüm konukların her söylediğine ikna olduğunun, televizyonda söylenen sağlık bilgisine daha çok itibar ettiğini; (Katılımcı 3) ise aksine bu fikre katılmadığını sağlık ile ilgili bilgiyi izleyici, birincil grup olarak tanımladığımız yakınlarından, özellikle sağ ık alanında çalışıyor ise onlardan yeniden doğrulattığını söyleyerek itiraz etmiştir.

\section{Sonuç}

Alımlıma analizi, izleyici çalışmaları alanında yeni yaklaşımlardandır. Genel olarak çıkış noktasını beşeri ve sosyal bilim araştırmalarının sahip olduğu sınırlamalardan alır. Alımlama analizi, izleyici-içerik ilişkisine dair hem nitel hem de ampirik nitelikte bir çözümleme geliştirir. Derinlikli söyleşi ve gözlemlerle izleyici hakkında ampirik veriler elde ederken bu verileri içeriğe dair verilerle karşılaştıran nitel yöntemler kullanır. Amaç alımlama ile ilgili süreçleri inceleyip, medya içeriğinin kullanım ve etkileriyle ilgili bir tavır geliştirebilmektir(Jensen \& Rosengren, 2005, s. 63-64).

Günümüz tüketim toplumlarında, tüketim ihtiyaçtan çok prestij, farklılık, bir gruba aidiyet, kimlik ve imaj edinme sınıf atlama gibi simgeler adına yapılmaktadır. Medya içerikleri, tüketiciye metaları kullanarak sınıf atlayacağı, yaşamının olumlu anlamda değişeceği, bir gruba ait olacağı ya da farklı olacağı türünde iletiler sunmaktadır(Dağtaş \& Dağtaş, 2009, s. 7).

Medya ürettiği söylemler aracılığı ile temsil ettiği ideolojileri pekiştirir ve gündelik yaşama sokar. Sağlık politikaları açısından da durum böyledir. Medyada sağlık programlarındaki söylemler dolayımıyla, sağlık politikalarının ideolojik konumları pekiştirilmektedir.Atabek ve diğerleri (2015) Kanal 7'de yayınlanan "Dr. Feridun Kunak Show" ve Kanal D'de yayınlanan "Doktorum" programlarını, sağlık programlarının seyirci üzerinde ideolojik konumlarınıinceledikleri çalışmalarında; Televizyon kanallarının farklı ideoloji konumlarına (yeni muhafazakâr, yeni liberal) karşın temel sağlık politikaları açısından çok da farklı söylemler üretmedikleri yönünde gözlemde bulunmuşlardır.

Yine İncilay Cangöz'ün(1999) “Kitle Illetişim Kuramlarında Etki Sorunsalı Bir İzleyici Araştırması” isimli doktora tezinde Kanal D Televizyonunda yayınlanan "Arena” programının alımlama çalışmasında, izleyici-metin etkileşimini Hall'un öne sürdüğü hegemonik, müzakereli ve eleştirel okuma modeli doğrultusuna araştırmış olup, seyircinin programı hegemonik söylemde alımladığını saptamıştır.

Türkiye'de son on yılda tecrübe edinilen ekonomik rahatlama ve sermayenin farklı toplumsal sınıflara yayılması, kendine özgü bir yaşam tarzı ve tüketim pratikleriyle yeni muhafazakâr bir orta sınıfın yükselmesine sebep olmuştur. 1990'ların başından sonra ise elde edilen siyasi mevziler ve ekonomik güçlenmeyle birlikte muhafazakâr kadının temel derdi kamusal alanda "en şık şekliyle görünme" olmuştur. Bu kadınların dönüşümleri sonucu; "tesettürle eğlence", "tesettürle şık kıyafet", "tesettürle moda" kavramları bir arada kullanılabilir hale gelmiştir.Kamusal alanın imaja dayalı değerlendirme kriterleri iş hayatında daha iyi yerlere gelmek isteyen muhafazakâr kadınlar için modern ve bakımlı görünmeyi adeta zorunlu kılmıştır.

Abraham Maslow'un ihtiyaçlar hiyerarşisi teorisinde her ihtiyaç kategorisinde ayrı bir kişilik gelişme düzeyinin var olduğu ve bireylerin bir alt kategoride tanımlanmış ihtiyaçları tam olarak gidermeden bir üst kategorideki intiyaçların kişiyi tatmin edemeyeceğini ve kişiliğin gelişiminin sekteye uğrayacağını ileri sürmektedir(Şahin, 2009, s. 106). Maslow'un ihtiyaçlar hiyerarşisinin dördüncü basamağında yer alan "saygınlık gereksinimini," orta-üst SES kategorisinde yer alan muhafazakâr kadın, medyanın metalaştırdığı ve yapmaz ise eksik hissedeceği bedenin güzelleşmesini bu bağlamda rasyonelleştirecektir. 
Çalışmada, grup üyeleri katılımcılar doğal olarak, formal eğitimlerinden bağımsız olmayarak, bir ön kabulle programa ve içeriğine yaklaşmışlardır.Her ne kadar, eğitimli ve bu alanda yüksek bilince sahip bir grup olsa da sağlık söz konusu olduğunda, estetik operasyonun tercihi muhafazakâr kimliğin veya dini referansların önüne geçtiği gözlemlenmiştir. Çalışma grubu, sağlık gibi gerekçelerle, tüketim toplumundabir meta dönüşen sağlığın bu tarafını rasyonelleştirmiştir.

Kamusal alanda muhafazakâr kimliğiyle var olma mücadelesi veren kadın özne, medya aracılığıyla daha çok tüketime yönelik sunulan medikal/estetik sağlık programlarının tüketimi karşısında, içinde bulunduğu sosyal kimliğin sınırlarının sebep olduğu iç çatışmalarına rağmen, dini referanslara gönderme yaparak muhafazakâr kadın izleyici olarak her ne kadar etkin olarak kendini görse de kaçınılmaz bir şekilde edilgen bir özne olarak konumlandırılabilmektedir.

Morley'e göre(Rahte, 2013)araştırmacı, etnografi çalışmalarında, inceleme konusu yaptığı kültürel topluluğu, kendi özgül koşulları içinde yorumlayarak genellemelere değil, duruma özgü yorumlamalara ulaşmayı hedefler. Çalışmanın, daha geniş şekilde, eğitim ve sağlık farkındalığının daha düşük/farklı olan bir muhafazakâr kadın izleyici grup üzerinde yapıldığında farklı bulguların elde edileceği ve bu izleyicinin etkin/edilgen rolünün değişiklik göstereceği düşünülmektedir.

\section{Kaynakça}

Atabek, Ü., Atabek, G., \& Bilge, D. (2015). Televizyon Sağlık Programlarında İdeolojik Söylemler. Galatasaray Üniversitesi Iletişim Dergisi( Özel Sayı 3), 11-29.

Aydın, O. Ş. (2007/2). Alımlama Araştırmaları ve Kültürel Çalışmalar Geleneğinin Katkısı. İstanbul Ticaret Üniversitesi Sosyal Bilimler Dergisi, s. 119-131.

Balkanlıŏlu, E. (2014). Türkiye'de Muhafazakar Kadın Modernleşmesi ve İslami Moda Dergilerindeki Yeni Muhafazakar Kadın. (Yayınlanmamış yüksek Lisans Tezi).İstanbul Üniversitesi /Sosyal Bilimler Enstitüsü Kadın Çalışmaları Bilim Dalı, İstanbul.

Baudrillard, J. (2004). Tüketim Toplumu. Hazal Deliceçaylı, Ferda Keskin (Çev.) İstanbul: Ayrıntı Yayınları.

Cangöz, i. (1999). Kitle İletişim Kuramlarında Etki Sorunsalı ve Bir İzleyici Araştırması , (Yayınlanmamış doktora tezi ). Anadolu Üniversitesi, Eskişehir.

Dağtaş, B., \& Dağtaş, E. (2009). Medya Tüketim Kültürü ve Yaşam Tarzları. Ankara: Ütopya.

Ergül, H.( Derl.) (2013). Sahanın Sesleri-iletişim Araştırmalarında Etnografik Yöntem- İstanbul Bilgi Üniversitesi Yayınları.

Göle, N. (2014). Modern Mahrem Medeniyet ve Örtünme. İstanbul: Metis.

Hall, S. (2005). Kodlama Kodaçımlama. Yiğit Yavuz (Çev. ), Şahinde Yavuz (Derl.), "Medya ve İzleyici Bitmeyen Tartışma içinde( s. 85-98 ).Ankara : Vadi Yayınları.

Jensen, K. B., \& Rosengren, K. E. (2005).izleyici Peşinde Beş Gelenek.Şahinde Yavuz, Yiğit Yavuz, (Çev.)Medya ve İleyici-Bitmeyen Tartışma içinde(s. 55-84) (Şahinde Yavuz Derl.) Ankara: Vadi Yayınları.

Karakaya, H. (2015). Türkiye'de Dindar Burjuva ve Kadın (Yayınlanmamış doktora tezi ).Atatürk Üniversitesi Felsefe ve Din Bilimleri ABD, Erzurum. 
Korkmaz, N. (2009).Türkiye'de Tüketim Kültürü ve Mekansal Ayrışma. Banu Dağtaş, Erdal Dağtaş (Derl.) Medya Tüketim Kültürü ve Yaşam Tarzları içinde (s. 142-164).Ankara: Ütopya.

Marshall, G. (1999). Sosyoloji Sözlüğü. Osman Akınhay,Derya Kömürcü (Çev.) Ankara: Bilim ve Sanat Yayınları.

McQuail, D., \& Windhal, S. (1997). Kitle Iletişim Modelleri, Konca Yumlu (Çev. ) Ankara: İmge Kitapevi.

Morley, D. (1992). Television Audience \& Cultures Studies . London: Routledge .

Özdemir, ì. (2009). Türkiye'de Popüler Kadın Magazin Dergileri: Yeni Kadın Kimliği ve Sunulan Yaşam Tarzları. Banu Dağtaş, Erdal Dağtaş (Derl.) Medya Tüketim Kültürü ve Yaşam Tarzları içinde (s. 202-129). Ankara: Ütopya.

Rahte, E. Ç. (2013). Gündüz Kuşağı Televizyonunun Etnografik Analizi: Bir İntrospektif Çalışması. Hakan Ergül ( Derl.)Sahanın Sesleri Iletişim Araştırmalarında Etnografik Yöntem içerisinde(s. 17-53). İstanbul: İstanbul Bilgi Üniversitesi Yayınları.

Şahin, Ç. E. (2009). Tüketim Toplumu: Mükemmele Evrilen Politika. Banu Dağtaş, Erdal Dağtaş (Derl.) Medya Tüketim Kültürü ve Yaşam Tarzları içinde (s. 103-141). Ankara: Ütopya.

Tokgöz, O. (2015). Iletişim Kuramlarına Anlam Vermek -Başlangıçtan Günümüze Anglo-Amerikan Iletişim Kuramı. Ankara: Imge Yayınevi.

Türköz, E. N. (2011). Türkiye'de Muhafazakar Kimliğin Inşası. (Yayınlanmamış yüksek Lisans Tezi) Afyon Kocatepe Üniversitesi/Sosyal Bilimler Enstitüsü Sosyoloji Ana Bilim Dalı, Afyon.

Yücebaş, S. (2013). Gündelik Yaşamm Estetiğinin Muhafazkar Biçimi:Muafazakar Yazılı Basında Yeni Yaşam Tarzları. (Yayınlanmamış doktora tezi).Ege Üniversitesi Sosyal Bilimler Enstitüsü Genel Gazetecilik ABD, İzmir. 